\title{
Oral administration of heat-killed Lactobacillus kunkeei YB38 improves murine influenza pneumonia by enhancing IgA production
}

\author{
Takashi ASAMA $^{1 * a}$, Takayuki UEMATSU2a, Noritada KOBAYASHI², Tomoki TATEFUJI ${ }^{1}$ and \\ Ken HASHIMOTO ${ }^{1}$ \\ ${ }^{1}$ Institute for Bee Products and Health Science, Yamada Bee Company, Inc., 194 Ichiba, Kagamino-cho, Tomata-gun, Okayama \\ 708-0393, Japan \\ ${ }^{2}$ Biomedical Laboratory, Division of Biomedical Research, Kitasato University Medical Center, 6-100 Arai, Kitamoto, Saitama \\ 364-8501, Japan
}

Received May 25, 2016; Accepted September 26, 2016; Published online in J-STAGE October 15, 2016

Influenza is one of the important respiratory tract infections that require special attention for maintaining health and hygiene. The removal of influenza virus (IFV) by secretory IgA produced by the respiratory epithelium has been reported to be a critical host defense mechanism. Therefore, we isolated Lactobacillus kunkeei YB38 (YB38), the promoter of the salivary IgA secretion in humans, from honeybee pollen and studied the effect of heat-killed YB38 treatment for preventing IFV infection in a mouse model. Female BALB/c mice received YB38 orally for 21 consecutive days and were then inoculated nasally with IFV. The YB38-treated group with a daily dose of $100 \mathrm{mg} / \mathrm{kg} \mathrm{showed} \mathrm{an}$ increased survival rate after IFV infection relative to the control. IgA secretion in the respiratory epithelium in the YB38-treated group $(100 \mathrm{mg} / \mathrm{kg})$ was significantly increased after 6 days of infection, while IL-6 production in the same respiratory site and the number of cells infiltrating into alveoli were significantly decreased. Moreover, lung tissue damage that appeared after IFV infection was reduced. These results suggested that the YB38 dose induced early and local IgA secretion at the infection site, inhibited persistent IFV infection, and prevented the infiltration of inflammatory immune cells or production of excessive IL-6, resulting in less damage to lung tissues.

Key words: influenza virus, mice, Lactobacillus kunkeei YB38, immunoglobulin A

\section{INTRODUCTION}

Influenza viruses (IFVs) are well known to cause highly contagious respiratory illnesses in humans and several animal species $[1,2]$. Influenza epidemics occur almost every winter, and the social and economic damage caused by severe influenza pandemics is an important issue in many countries. Aberrant production of inflammatory cytokines, such as tumor necrosis factor- $\alpha$ (TNF- $\alpha$ ), interleukin-6 (IL-6), and interferon (IFN), is frequently observed in the course of lethal infections with IFVs, and this is thought to be an important factor linked to viral pathogenicity [3-6]. In addition, IFV

\footnotetext{
a These authors contributed equally to this work.

*Corresponding author. Takashi Asama, Institute for Bee Products and Health Science, Yamada Bee Company, Inc., 194 Ichiba, Kagamino-cho, Tomata-gun, Okayama 708-0393, Japan. E-mail: ta1022@yamada-bee.com

(C)2017 BMFH Press

This is an open-access article distributed under the terms of the Creative Commons Attribution Non-Commercial No Derivatives (bync-nd) License $<$ http://creativecommons.org/licenses/by-nc-nd/4.0/>.
}

infections are quite dangerous to specific populations, such as pregnant women, diabetes patients, infants, and the elderly, who are known to be high-risk groups $[7,8]$. Since these groups display some deficiencies in immune responses, viral infections in these high-risk groups frequently lead to severe and sometimes even lethal conditions. Therefore, maintaining the immune system in an appropriately robust condition is thought to be important for the prevention of the severe symptoms of IFV infection.

Lactic acid bacteria (LAB) help regulate intestinal microflora and immunomodulatory properties [9]. A lot of reports have shown that LAB are effective at enhancing host immunity [10] and put up a defense against pathogen infection [11]. Lactobacillus kunkeei YB38 (YB38) is a LAB isolated from honeybee (Apis mellifera) pollen with the ability to improve immune responses such as IgA production in healthy adults [12]. The primary role of mucosal $\operatorname{IgA}$ is to neutralize inhaled bacteria and viruses by interfering with their motility or by inhibiting their adherence to epithelial cells [13]. Secretary IgA antibodies in the mucosa are 
therefore believed to provide the primary defense against respiratory IFV infection [14].

The aim of this study was to examine the antiviral effects on IFV infection after oral administration of a heat-killed YB38 treatment in mice.

\section{MATERIALS AND METHODS}

\section{Bacteria}

The Lactobacillus kunkeei YB38 strain (FERM BP-11439) was prepared as described previously [12]. This strain was cultured at $30^{\circ} \mathrm{C}$ for $24 \mathrm{hr}$ in a medium containing yeast extract and high fructose corn syrup. The bacterial cells were collected by centrifugation, filtered, heat-killed at $80^{\circ} \mathrm{C}$ for $1 \mathrm{~min}$, and freeze-dried for storage. The bacterial deposit was resuspended in saline solution before use.

\section{Cells}

Madin-Darby canine kidney (MDCK) cells were obtained from JCRB Cell Bank (Osaka, Japan). MDCK cells were grown in Eagle's minimum essential medium (Wako Pure Chemical Industries, Osaka, Japan) supplemented with $10 \%$ fetal bovine serum (Life Technologies, Carlsbad, CA, USA) and antibiotics (100 $\mathrm{IU} / \mathrm{ml}$ penicillin and $100 \mathrm{mg} / \mathrm{ml}$ streptomycin; SigmaAldrich, St. Louis, MO, USA).

\section{Virus}

The IFV A/PR/8/34 strain (H1N1 isotype) was kindly provided by the Kitasato Institute (Tokyo, Japan) and prepared as described previously [15].

\section{Mice}

Five-week-old female BALB/c mice were purchased from Japan SLC (Shizuoka, Japan) and acclimatized for 1 week. The animals were housed under specific pathogen-free conditions. All experiments were approved by the Institutional Animal Care and Use Committee for Kitasato University Medical Center (No. 24-4), and animals were treated in accordance with the Regulations for Animal Experiments in Kitasato University.

\section{Antibodies}

Fluorescein isothiocyanate (FITC)-conjugated antiLy-6B.2 (clone 7/4) monoclonal antibody was purchased from AbD Serotec (Oxford, UK). Phycoerythrin (PE)-conjugated anti-Gr-1 (clone RB6-8C5), biotinconjugated anti-NK1.1 (clone PK136), phycoerythrinCy5 (PC5)-conjugated anti- CD19 (clone 6D5), and phycoerythrin-Cy7 (PC7)-conjugated anti-CD3 $\varepsilon$ (clone
145-2C11) monoclonal antibodies were purchased from BioLegend (San Diego, CA, USA).

\section{IFV lethal infection in mice}

Six-week-old BALB/c mice were divided into 3 groups of 20 mice each on the first day. The YB38 saline dilution was administered as daily oral doses of 0,10 , or $100 \mathrm{mg} /$ $\mathrm{kg}$ during the entire experimental period. The control group received saline solution by gavage. On day 22, the mice were anesthetized by intramuscular injections with a mixture of $25 \mathrm{mg} / \mathrm{kg}$ ketamine hydrochloride (Daiichi Sankyo, Tokyo, Japan) and $0.625 \mathrm{mg} / \mathrm{kg}$ droperidol (Daiichi Sankyo) into the hind legs. Then, $10^{3}$ plaque forming units (PFU) of saline-diluted IFV were inoculated into the right nasal cavity of each mouse. The mouse survival rate was monitored daily for up to 21 days after IFV infection.

\section{IFV sublethal infection in mice}

Six-week-old BALB/c mice were divided into 2 groups of 50 mice each on day 1 of the study. The YB38 saline dilution was administered as daily oral doses of 0 or $100 \mathrm{mg} / \mathrm{kg}$ during the experimental period. The control group received saline solution by gavage. On day $22,10^{2}$ PFU of saline-diluted IFV were administrated nasally in the same manner as the IFV lethal infection model. On days 22 (before infection), 24 (2 days after infection), 26 (4 days after infection), 28 (6 days after infection), 30 (8 days after infection), and 36 (14 days after infection), lungs and bronchoalveolar lavage fluid were collected from mice in each group.

\section{Histology}

Lungs were collected at $0,2,4,6,8$, and 14 days after IFV infection. Paraffin embedding and hematoxylin and eosin staining of tissues were performed using standard methodologies.

\section{Bronchoalveolar lavage (BAL)}

BAL was carried out as described previously [16-18]. In brief, mice tracheas were cannulated with $1.2-\mathrm{mm}$ diameter polyethylene catheters. Lungs were instilled with $1 \mathrm{ml}$ of pre-warmed PBS containing $5 \mathrm{mM}$ EDTA, followed by the retrieval of lavage fluid aliquots. Cells in the BAL fluid (BALF) were counted after red blood cell lysis and subjected to flow cytometric analysis. The supernatants of the BALF were subjected to analysis of the expression of multiple cytokines.

\section{Cytokine expression}

Detection of multiple cytokines in the BALF 
was performed with a FlowCytomix Cytokine Bead Assay (Bender MedSystems, Vienna, Austria). All measurements were performed in triplicate.

\section{Flow cytometry}

BALF cells were suspended in mouse FcR Blocking Reagent (Miltenyi Biotec, Bergisch Gladbach, Germany) for $10 \mathrm{~min}$ before staining with FITC-, PE-, biotin-, PC5-, or PC7-conjugated antibodies. After staining, biotinylated antibodies were visualized with streptavidinenergy-coupled dye (Beckman Coulter, Fullerton, CA, USA). The antibodies used were anti-Ly-6B.2, anti-Gr-1, anti-NK1.1, anti-CD19, and anti-CD3e. Stained cells were analyzed with a Cytomics FC500 flow cytometer (Beckman Coulter) and the Flowjo software (Tree Star, Ashland, OR, USA).

\section{Viral copy nembers}

The mice were euthanized by intraperitoneal administration of sodium pentobarbital at $0,2,4,6$, 8 , or 14 days after IFV infection. Lung tissues were homogenized using a gentleMACS dissociator (Miltenyi Biotec), and RNA was extracted with an Isogen II RNA extraction kit (Nippon Gene, Tokyo, Japan). Reverse transcription was conducted with the Uni-12 primer (5'- AGC AAA AGC AGG -3') [19], and quantitative RT-PCR (qPCR) was performed with primers specific for NP (forward: 5'- GAT TGG TGG AAT TGG ACG AT -3'; reverse: 5'- AGA GCA CCA TTC TCT CTA TT -3') using an Applied Biosystems 7900HT Fast Real-Time PCR System (Life Technologies, Carlsbad, CA, USA). The standard calibration curve for qPCR was obtained by stepwise dilution of a cloned NP gene fragment with a known copy number.

\section{Antigen-specific antibody titer}

$\mathrm{B}$ cell-mediated humoral responses were measured as virion-specific immunoglobulin production by ELISA, as previously described [20]. Briefly, 96-well ELISA plates (Corning, Corning, NY, USA) were coated with ultrasonicated IFV virions (A/PR/8/34 strain) at $5 \times 10^{6}$ $\mathrm{PFU} / \mathrm{ml}$ in a carbonate buffer $(\mathrm{pH} 9.6)$, and incubated overnight at $4^{\circ} \mathrm{C}$. Plates were then washed with PBS containing $0.05 \%$ Tween 20 (Wako Pure Chemical Industries, Osaka, Japan). BALF collected from mice on days 0 and 14 after IFV infection were serially diluted with PBS/Tween 20 containing 5\% skim milk, applied onto the virion-coated plates, and incubated for $2 \mathrm{hr}$ at room temperature. After washing, goat antimouse total IgA conjugated to horseradish peroxidase (Jackson ImmunoResearch, Baltimore Pike, PA, USA) was applied and incubated for $2 \mathrm{hr}$ at room temperature. After washing, the plates were stained with a TMB Substrate Set (BioLegend). The reaction was terminated with $1 \mathrm{M} \mathrm{H}_{2} \mathrm{SO}_{4}$ (Wako Pure Chemical Industries), and the absorbance was measured. Total IgA in BALF was measured by using Mouse IgA ELISA Ready-SET-Go! (Affymetrix, Santa Clara, CA, USA) according to the manufacturer's usage instructions.

\section{Statistical analysis}

Survival curves were generated by the Kaplan-Meier method, and statistical analyses were performed using the log-rank test. Statistical significance was assessed by unpaired Student's t-test. A p value $<0.05$ was considered significant.

\section{RESULTS}

\section{Survival analysis after IFV infection}

The protective effects of orally administrated heatkilled YB38 on the IFV-infected mice were evaluated. Each heat-killed YB38-treated group received a daily oral dose of 10 or $100 \mathrm{mg} / \mathrm{kg} /$ day. On day 22 , the mice were infected with $10^{3} \mathrm{PFU} /$ mouse IFV. An obvious improvement was noticed in the survival rate with the administration of $100 \mathrm{mg} / \mathrm{kg} /$ day in the case of the heatkilled YB38-treated group (Fig. 1). Half of the mice in the control group survived for 9 days, and the survival rate reached a plateau on day 13 after IFV infection. In the $100 \mathrm{mg} / \mathrm{kg}$ /day heat-killed YB38 group, 50\% of the mice survived more than 21 days after IFV infection. Thus, the survival time was significantly longer for the $100 \mathrm{mg} / \mathrm{kg} /$ day heat-killed YB38-treated group than the control group (Fig. 1; $<<0.05$ ).

\section{Viral replication in the lungs after IFV infection}

The mouse survival rate was improved with daily oral administration of heat-killed YB38. Therefore, to evaluate the effect of oral administration of the heatkilled YB38 on the replication of IFV, the relative number of genomic RNA copies contained in the preparation samples was confirmed by qPCR. As shown in Fig. 2, the results indicated that the relative number of the genomic RNA copies in the lungs was significantly decreased in the heat-killed YB38-treated group after 14 days of infection, while after $2,4,6$, and 8 days of infection, significant changes were not confirmed (Fig. 2).

\section{The number of infiltrated cells in the lung after IFV} infection

To investigate the number of infiltrated cells in the 


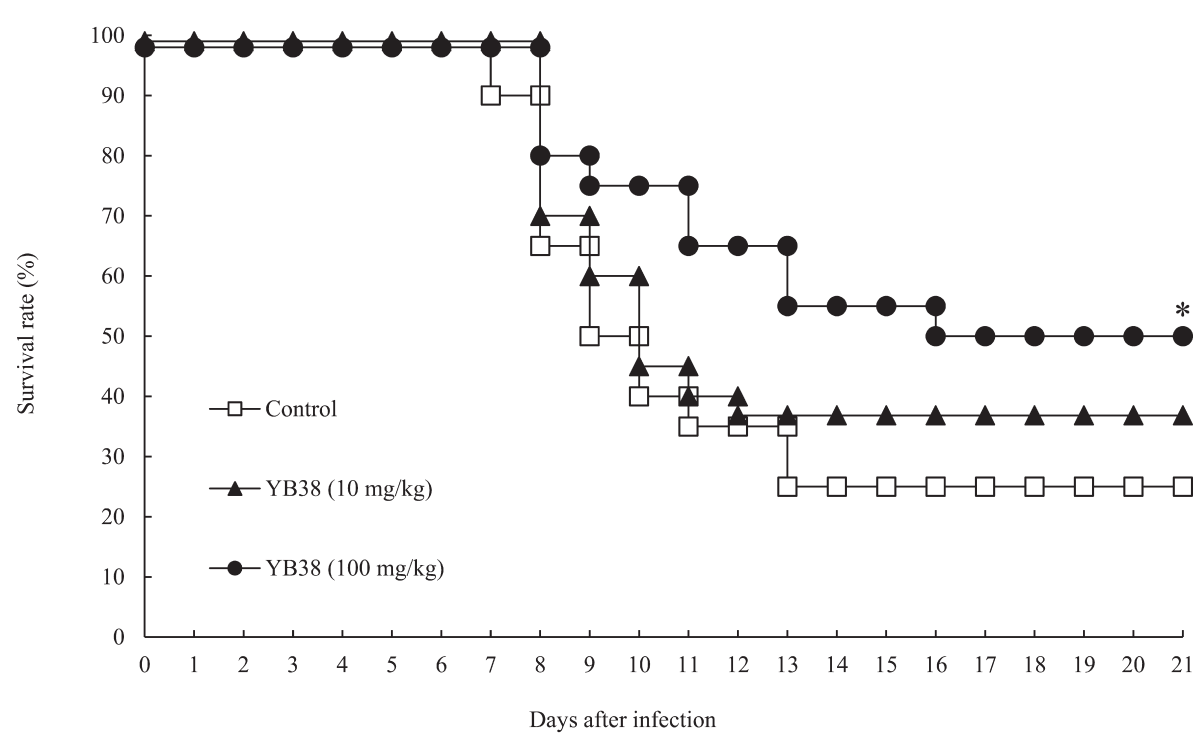

Fig. 1. The protective effects of orally administrated YB38 on IFV-infected mice.

Each YB38-treated group was continuously orally administered 10 or $100 \mathrm{mg} / \mathrm{kg}$ mouse diluted in saline during the experimental period. The control group was administered saline solution. On day 22 ( 0 days after infection), the mice were infected with $10^{3} \mathrm{PFU}$ of saline-diluted IFV. The viability of the mice was observed daily for 21 days after infection. Each group comprised 20 mice. Significant differences were observed versus the control by log-rank test with Student's t-test $\left({ }^{*} \mathrm{p}<0.05\right)$.

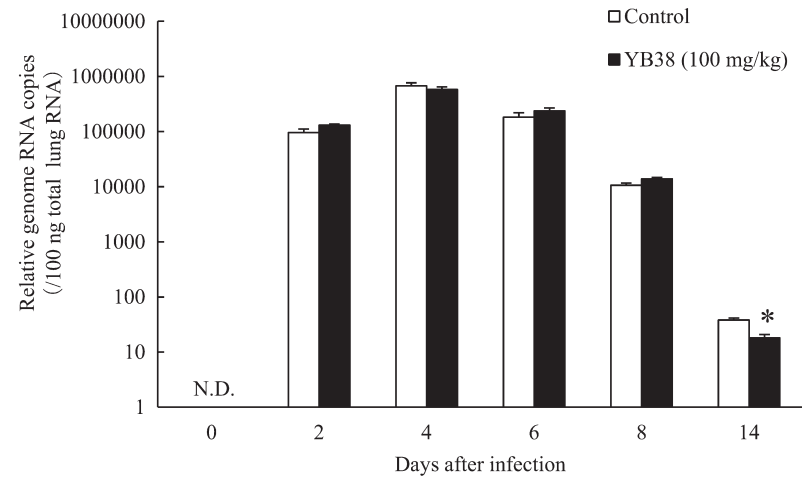

Fig. 2. The effect of orally administered YB38 on the relative number of genomic RNA copies of IFV in the lungs of mice.

Each YB38-treated group was continuously orally administered a saline-diluted dose of $100 \mathrm{mg} / \mathrm{kg}$ mouse during the experimental period. The control group was treated with saline solution. On day 22 ( 0 days after infection), the mice were infected with $10^{2} \mathrm{PFU}$ of saline-diluted IFV. The IFV RNA copy number was evaluated at 0 , $2,4,6,8$, or 14 days after IFV infection. Each group comprised 25 mice. Each value is the mean \pm SD. Significant differences were observed versus the control by Student's t-test $\left({ }^{*} \mathrm{p}<0.05\right)$. N.D.: Not detected.

lungs after IFV infection, we measured the numbers of $\mathrm{T}$ cells $\left(\mathrm{CD} 3 \varepsilon^{+}\right)$, B cells $\left(\mathrm{CD} 19^{+}\right)$, NK cells $\left(\mathrm{NK} 1.1^{+}\right)$, neutrophils (Gr-1 $1^{+}$Ly6B $.2^{+}$), and macrophages (Gr-
$1^{+}$Ly6B.2-) in BALF. The numbers of T cells, NK cells, neutrophils, and macrophages were significantly lower in the mice inoculated with the heat-killed YB38 treatment compared with the control at 4 days, 4-8 days, 4-6 days, and 8 days after infection, respectively (Fig. 3B, D-F). On the other hand, the number of B cells was significantly higher in the heat-killed YB38-treated group compared with the control (Fig. 3C).

\section{Cytokine production in the lungs after IFV infection}

It has been reported that massive cell infiltration into the lungs and excessive proinflammatory cytokine production frequently occur in the course of influenza virus infections $[21,22]$, so we evaluated IL-6, TNF- $\alpha$, and IFN- $\gamma$ production in BALF after infection. IL-6 production was significantly suppressed in the heatkilled YB38-treated group compared with the control at 4,6 , and 8 days after infection (Fig. 4A), while TNF- $\alpha$ and IFN- $\gamma$ production was not changed in the heat-killed YB38-treated and control groups (Fig. 4B, C).

\section{IgA production in the lung and serum after IFV infection}

Secretary IgA antibodies in the mucosa are believed to provide the primary defense against respiratory influenza viruse infection [14]. Therefore, we measured $\operatorname{IgA}$ production in the lung and serum. The total concentration 
(A)

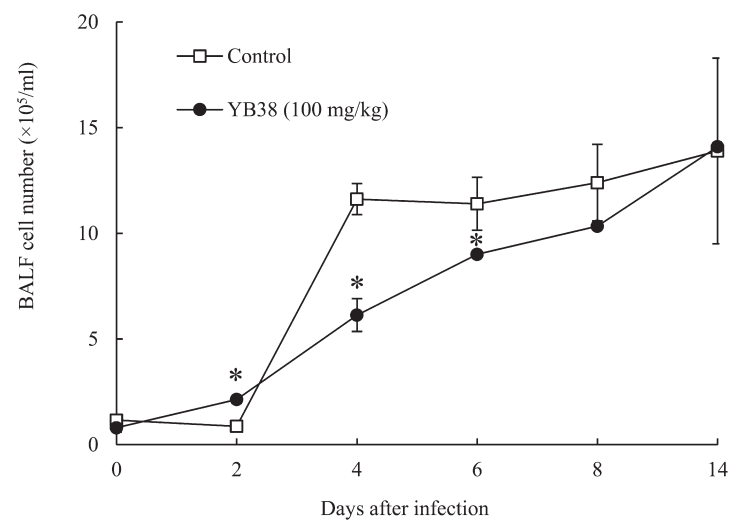

(C)

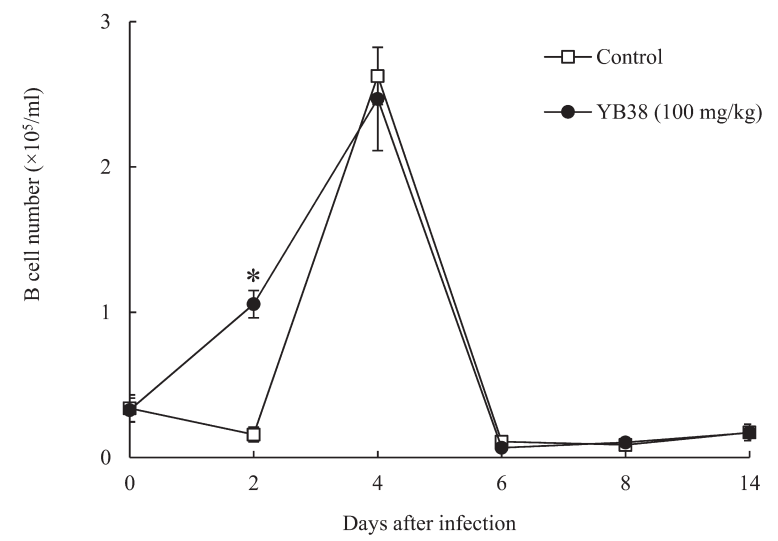

(E)

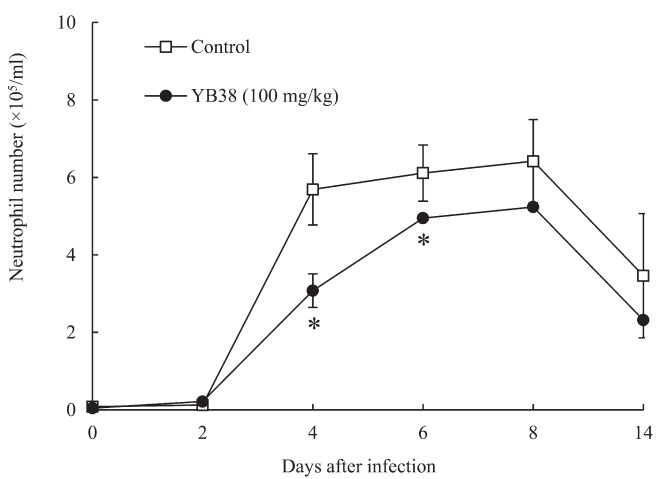

(B)

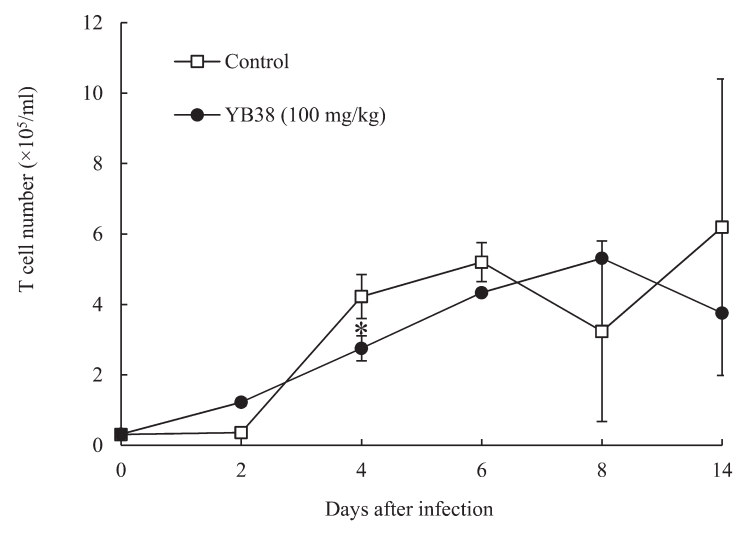

(D)

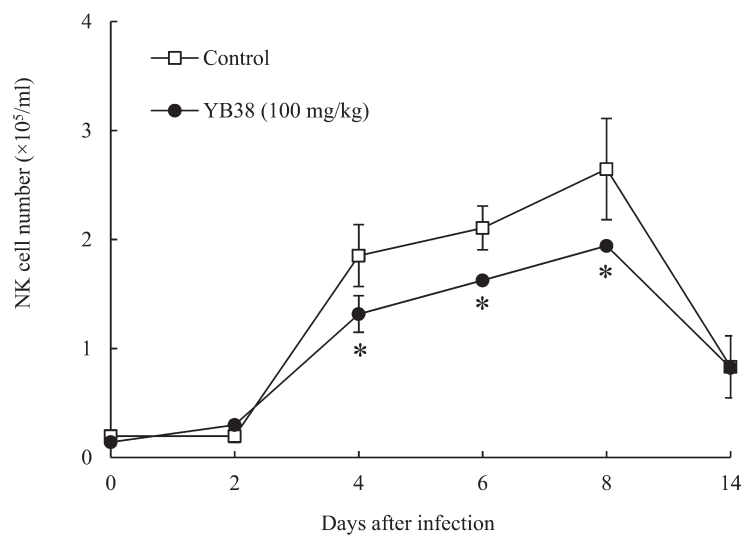

(F)

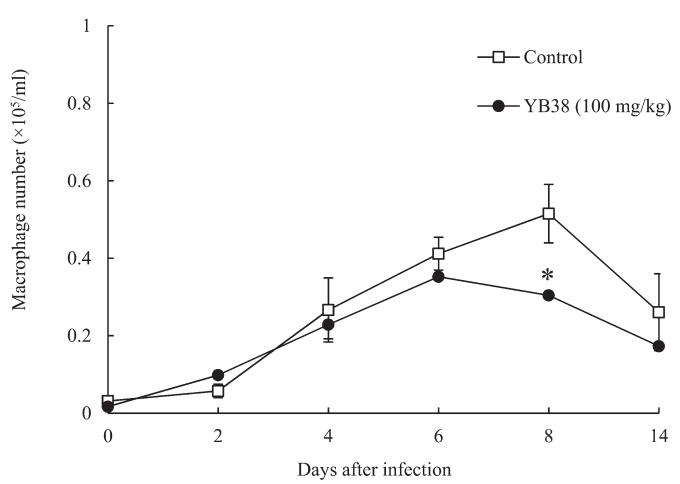

Fig. 3. The effect of orally administered YB38 on the number of infiltrated cells in the lung of IFV-infected mice.

After YB38 was administrated to mice, the IFV infections were examined as described in Fig. 2. Evaluation of infiltrated cells number in the lung was conducted at 0, 2, 4, 6, 8, or 14 days after IFV infection. Each group comprised 25 mice. (A) Total BALF cells number, (B) T cells $\left(\mathrm{CD} 3 \varepsilon^{+}\right)$number, (C) B cells $\left(\mathrm{CD} 19^{+}\right)$number, (D) NK cells (NK1.1 $\left.{ }^{+}\right)$number, (E) Neutrophils $\left(\mathrm{Gr}-1^{+}\right.$Ly6B.2 $\left.2^{+}\right)$number, $(\mathrm{F}) \mathrm{Macrophages}$ $\left(\mathrm{Gr}-1^{+}\right.$Ly6B. $\left.2^{-}\right)$number. Each value is the mean \pm SD. Significant differences were observed versus the control by Student's t-test $(* \mathrm{p}<0.05)$. 
(A)

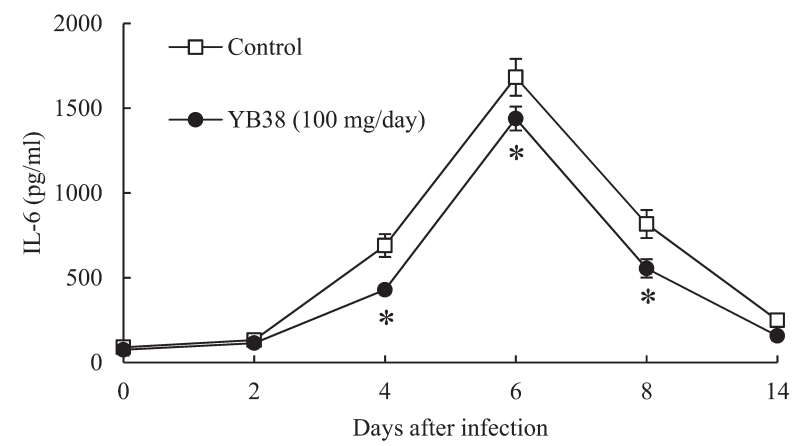

(B)

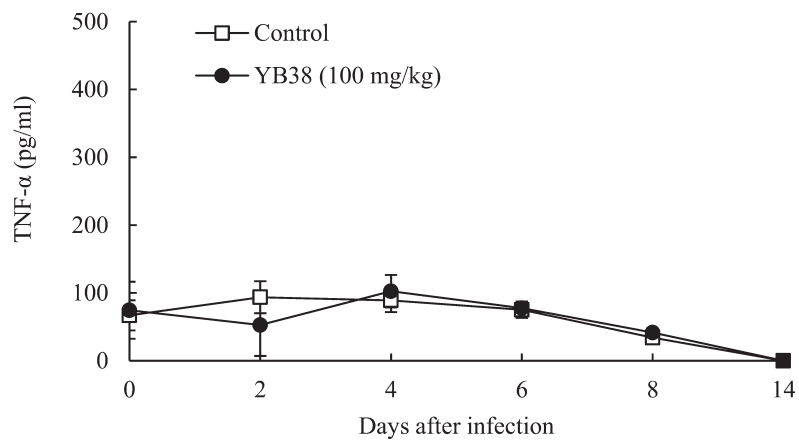

(C)

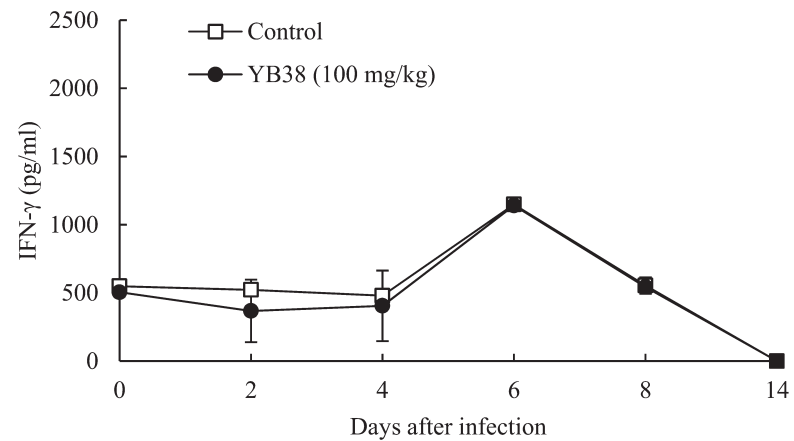

Fig. 4. Effect of orally administered YB38 on cytokine production in the lung of the IFV-infected mice.

After YB38 was administrated to mice, IFV infections were examined as described in Fig. 2. Cytokine production in the lung was evaluated at $0,2,4,6,8$, or 14 days after IFV infection. Each group comprised 25 mice. (A) IL-6, (B) TNF- $\alpha$, (C) IFN- $\gamma$. Each value is the mean $\pm \mathrm{SD}$. Significant differences were observed versus the control by Student's t-test $(* \mathrm{p}<0.05)$.

of IgA in BALF was significantly increased in the heatkilled YB38-treated group compared with the control at 6 and 8 days after infection; IFV-specific IgA production was considerably increased after 6 and 14 days of infection (Fig. 5A), with an important decrease at 8 days
(A)

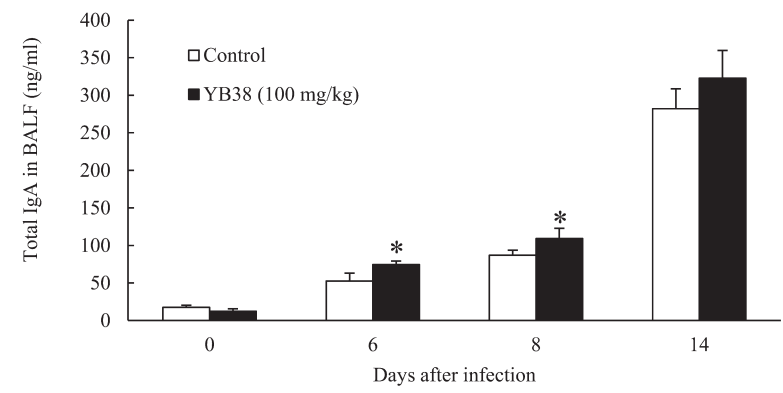

(B)

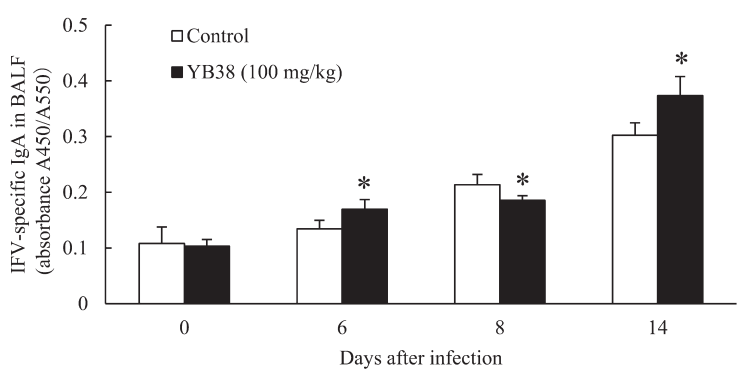

(C)

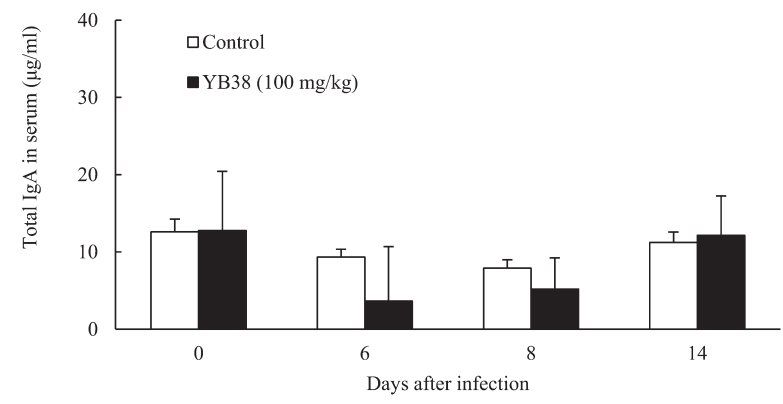

Fig. 5. Effect of orally administered YB38 on IgA production in BALF and serum of IFV-infected mice.

After YB38 was administrated to mice, IFV infections were examined as described in Fig. 2. The IgA production in BALF and serum was evaluated at $0,6,8$, or 14 days after IFV infection. Each group comprised 25 mice. (A) Total IgA in BALF, (B) IFV-specific IgA in BALF, (C) total IgA in serum. Each value is the mean \pm SD. Significant differences were observed versus the control by Student's t-test $(* \mathrm{p}<0.05)$.

after infection (Fig. 5B). These data indicated that the total IgA concentration in BALF was increased by oral administration of heat-killed YB38. However, the serum IgA production was not changed (Fig. 5C).

\section{Histopathological analysis of lung tissue after IFV infection}

In order to determine the progress of viral pneumonia, 


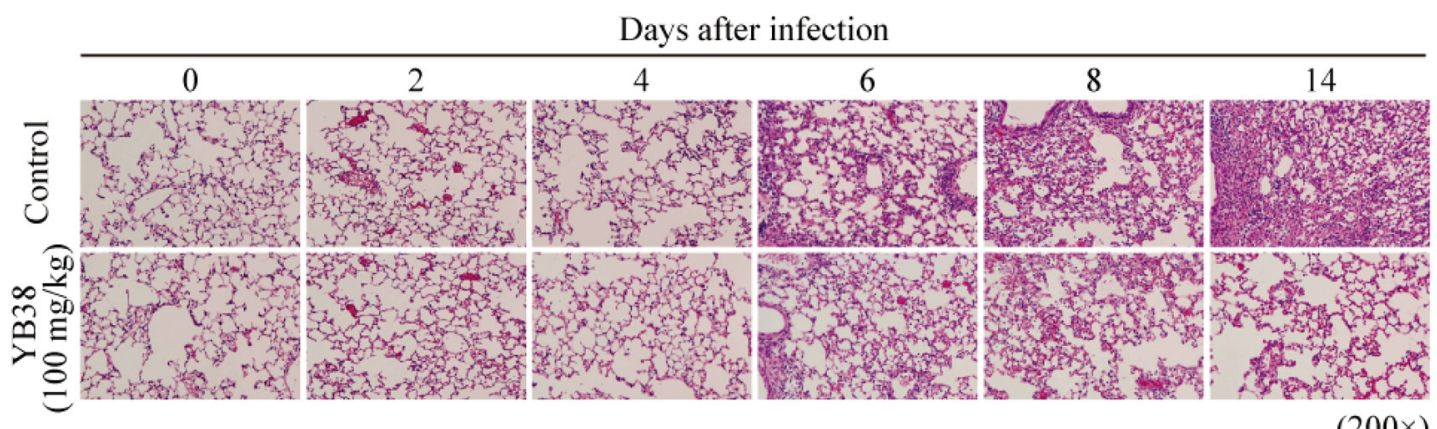

$(200 \times)$

Fig. 6. Lung injury in IFV-infected mice.

After YB38 was administrated to mice, IFV infections were examined as described in Fig. 2. Histopathological analysis of the lung tissue of mice was performed at $0,2,4,6$, 8, or 14 days after inoculation with IFV. Hematoxylin and eosin-stained tissue sections at magnifications of $\times 200$. Results are representative of two repeated experiments.

we examined serial pathological changes in the lungs of the mice infected with influenza virus. Invasion of lung cells associated with inflammation and thickening of bronchoalveolar walls were suppressed in the heat-killed YB38-treated group compared with the control at 6, 8, and 14 days after infection (Fig. 6).

\section{DISCUSSION}

We demonstrated that oral administration of a heatkilled YB38 treatment has a protective effect against influenza virus in a mouse model.

It has been reported that massive infiltration of cells into the lungs and excessive proinflammatory cytokine production frequently occur in the course of influenza virus infections [21, 22], and that secretory $\operatorname{IgA}$ is the major contributors to humoral mucosal immunity to influenza virus infection [23]. Therefore, we evaluated the number of infiltrated cells and the amount of produced proinflammatory cytokine such IL-6 and IgA in BALF as a means of assessment of IFV prevention.

In this study, the heat-killed YB38 treatment is considered to have suppressed IFV infection by early induction of $\operatorname{IgA}$ production from plasma cells in the respiratory mucosa. The results showed that the number of infiltrated cells in the case of oral administration of heat-killed YB38 decreased compared with the control starting on day 4 after IFV infection and that massive IL-6 production was suppressed after inflammatory cell in filtration in regional points of infection. This suppressive effect on inflammation is considered to suppress the damage in lung tissue. In agreement with the present study, Nakayama et al. [11] confirmed the protective effects against IFV infection, the suppressive effect on lymphocyte number, and the suppressive effect on the amount of IL- 6 caused by oral administration of Lactobacillus gasseri. Furthermore, Kobayashi et al. [15], Kikuchi et al. [24], and the present study reported the defensive effects against IFV infection and a promotional effect on IgA production in BALF. The difference between the present study and that of Kobayashi et al. lies in whether or not the serum IgA concentration increased as a result of lactic acid administration. This difference may be attributed to the different virus dosages: (in this study, the tested dose was $10^{2} \mathrm{PFU} / \mathrm{mouse}$, and Kobayashi et al. reported a dose of $\left.10^{5.95} \mathrm{TCID} / \mathrm{mouse}\right)$. In the present study, the mice were infected with IFV at a low dosage $\left(10^{2} \mathrm{PFU} /\right.$ mouse $)$ in a temporal sampling model to prevent death before sampling. So it was considered that clear change in the IgA serum concentration was not confirmed except in the lungs, the main target organs of IFV, because an infection becomes less severe if systemic spread of the virus is prevented. On the other hand, oral administration of the heat-killed YB38 may lead to an increase in serum IgA concentration following systemic IFV infection in a lethal infection model. Additionally, IgG at respiratory surfaces also works as the second-largest antibody contributor in elimination of IFV [25]. Although we could not fully examine the role of $\operatorname{IgG}$ in this study for rational reasons, we consider that oral administration of YB38 might also enhance $\mathrm{IgG}$ production at respiratory surfaces.

The mechanism of IgA induction is unclear. The factors related to increases of IgA production have been reported. TGF- $\beta$ induces IgA-specific T-cell-dependent class switch recombination [26-28]. APRIL and BAFF also act to induce IgM to IgA class switch recombination through $\mathrm{T}$ cell-independent pathways [29-31], whereas 
retinoic acid confers gut-homing properties to $\operatorname{IgA}^{+} \mathrm{B}$ cells [32, 33]. In addition, Tezuka et al. [34] demonstrated that iNOS regulates IgA class switch recombination through expression of the TGF- $\beta$ receptor and production of APRIL and BAFF. These factors can contribute to IgA induction caused by oral administration of heat-killed YB38, so further investigations are needed regarding the production of TGF- $\beta$, APRIL, BAFF, and iNOS.

In conclusion, we revealed that oral administration of the heat-killed YB38 was effective against influenza virus infection due to the IgA induction effect. It may be possible to confirm the newly revealed immunological effect of the heat-killed YB38 treatment by targeting the intestinal mucosa using the dextran sulfate sodiuminduced colitis model.

\section{Conflicts of interest}

There are no conflicts of interest.

\section{ACKNOWLEDGEMENT}

We thank Takashi Fukuyama, Tomoko Fujita and Taiga Yamazaki for helpful discussions and technical support.

\section{REFERENCES}

1. Taubenberger JK, Morens DM. 2010. Influenza: the once and future pandemic. Public Health Rep 125 Suppl 3: 16-26. [Medline]

2. McCaughey C. 2010. Influenza: a virus of our times. Ulster Med J 79: 46-51. [Medline]

3. Van Reeth K, Nauwynck H, Pensaert M. 1998. Bronchoalveolar interferon-alpha, tumor necrosis factor-alpha, interleukin-1, and inflammation during acute influenza in pigs: a possible model for humans? J Infect Dis 177: 1076-1079. [Medline] [CrossRef]

4. Julkunen I, Sareneva T, Pirhonen J, Ronni T, Melén K, Matikainen S. 2001. Molecular pathogenesis of influenza $A$ virus infection and virus-induced regulation of cytokine gene expression. Cytokine Growth Factor Rev 12: 171-180. [Medline] [CrossRef]

5. Kaiser L, Fritz RS, Straus SE, Gubareva L, Hayden FG. 2001. Symptom pathogenesis during acute influenza: interleukin-6 and other cytokine responses. J Med Virol 64: 262-268. [Medline] [CrossRef]

6. Mok KP, Wong CHK, Cheung CY, Chan MC, Lee SMY, Nicholls JM, Guan Y, Peiris JSM. 2009. Viral genetic determinants of $\mathrm{H} 5 \mathrm{~N} 1$ influenza viruses that contribute to cytokine dysregulation. J Infect Dis 200: 1104-1112. [Medline] [CrossRef]

7. Boyd M, Clezy K, Lindley R, Pearce R. 2006. Pandemic influenza: clinical issues. Med J Aust 185 Suppl: S44-S47. [Medline]

8. Lynch JP 3rd, Walsh EE. 2007. Influenza: evolving strategies in treatment and prevention. Semin Respir Crit Care Med 28: 144-158. [Medline] [CrossRef]

9. Tsai YT, Cheng PC, Pan TM. 2012. The immunomodulatory effects of lactic acid bacteria for improving immune functions and benefits. Appl Microbiol Biotechnol 96: 853-862. [Medline] [CrossRef]

10. Vinderola G, Perdigón G, Duarte J, Farnworth E, Matar C. 2006. Effects of the oral administration of the exopolysaccharide produced by Lactobacillus kefiranofaciens on the gut mucosal immunity. Cytokine 36: 254-260. [Medline] [CrossRef]

11. Nakayama Y, Moriya T, Sakai F, Ikeda N, Shiozaki T, Hosoya T, Nakagawa H, Miyazaki T. 2014. Oral administration of Lactobacillus gasseri SBT2055 is effective for preventing influenza in mice. Sci Rep 4: 4638. [Medline] [CrossRef]

12. Asama T, Arima TH, Gomi T, Keishi T, Tani H, Kimura Y, Tatefuji T, Hashimoto K. 2015. Lactobacillus kunkeei YB38 from honeybee products enhances IgA production in healthy adults. J Appl Microbiol 119: 818-826. [Medline] [CrossRef]

13. Fagarasan S, Honjo T. 2003. Intestinal IgA synthesis: regulation of front-line body defences. Nat Rev Immunol 3: 63-72. [Medline] [CrossRef]

14. Shvartsman YS, Zykov MP. 1976. Secretory antiinfluenza immunity. Adv Immunol 22: 291-330. [Medline] [CrossRef]

15. Kobayashi N, Saito T, Uematsu T, Kishi K, Toba M, Kohda N, Suzuki T. 2011. Oral administration of heatkilled Lactobacillus pentosus strain b240 augments protection against influenza virus infection in mice. Int Immunopharmacol 11: 199-203. [Medline] [CrossRef]

16. Seki M, Yanagihara K, Higashiyama Y, Fukuda Y, Kaneko Y, Ohno H, Miyazaki Y, Hirakata Y, Tomono K, Kadota J, Tashiro T, Kohno S. 2004. Immunokinetics in severe pneumonia due to influenza virus and bacteria coinfection in mice. Eur Respir J 24: 143-149. [Medline] [CrossRef]

17. Seki M, Kohno S, Newstead MW, Zeng X, Bhan U, Lukacs NW, Kunkel SL, Standiford TJ. 2010. Critical role of IL-1 receptor-associated kinase-M in regulating chemokine-dependent deleterious inflammation in murine influenza pneumonia. J Immunol 184: 14101418. [Medline] [CrossRef]

18. Uematsu T, Iizasa E, Kobayashi N, Yoshida H, Hara H. 2015. Loss of CARD9-mediated innate activation attenuates severe influenza pneumonia without compromising host viral immunity. Sci Rep 5: 17577. [Medline] [CrossRef]

19. Hoffmann E, Stech J, Guan Y, Webster RG, Perez DR. 2001. Universal primer set for the full-length amplification of all influenza A viruses. Arch Virol 146: 2275-2289. [Medline] [CrossRef]

20. Koyama S, Ishii KJ, Kumar H, Tanimoto T, Coban C, Uematsu S, Kawai T, Akira S. 2007. Differential role of 
TLR- and RLR-signaling in the immune responses to influenza A virus infection and vaccination. J Immunol 179: 4711-4720. [Medline] [CrossRef]

21. Kobasa D, Jones SM, Shinya K, Kash JC, Copps J, Ebihara H, Hatta Y, Kim JH, Halfmann P, Hatta M, Feldmann F, Alimonti JB, Fernando L, Li Y, Katze MG, Feldmann H, Kawaoka Y. 2007. Aberrant innate immune response in lethal infection of macaques with the 1918 influenza virus. Nature 445: 319-323. [Medline] [CrossRef]

22. Cillóniz C, Shinya K, Peng X, Korth MJ, Proll SC, Aicher LD, Carter VS, Chang JH, Kobasa D, Feldmann F, Strong JE, Feldmann H, Kawaoka Y, Katze MG. 2009. Lethal influenza virus infection in macaques is associated with early dysregulation of inflammatory related genes. PLoS Pathog 5: e1000604. [Medline] [CrossRef]

23. Suzuki T, Kawaguchi A, Ainai A, Tamura S, Ito R, Multihartina P, Setiawaty V, Pangesti KNA, Odagiri T, Tashiro M, Hasegawa H. 2015. Relationship of the quaternary structure of human secretory $\operatorname{IgA}$ to neutralization of influenza virus. Proc Natl Acad Sci USA 112: 7809-7814. [Medline] [CrossRef]

24. Kikuchi Y, Kunitoh-Asari A, Hayakawa K, Imai S, Kasuya K, Abe K, Adachi Y, Fukudome S, Takahashi Y, Hachimura S. 2014. Oral administration of Lactobacillus plantarum strain AYA enhances IgA secretion and provides survival protection against influenza virus infection in mice. PLoS One 9: e86416. [Medline] [CrossRef]

25. Brandtzaeg P. 1995. The role of humoral mucosal immunity in the induction and maintenance of chronic airway infections. Am J Respir Crit Care Med 151: 2081-2086, discussion 2086-2087. [Medline] [CrossRef]

26. Sonoda E, Matsumoto R, Hitoshi Y, Ishii T, Sugimoto M, Araki S, Tominaga A, Yamaguchi N, Takatsu K. 1989. Transforming growth factor beta induces IgA production and acts additively with interleukin 5 for IgA production. J Exp Med 170: 1415-1420. [Medline]
[CrossRef]

27. Coffman RL, Lebman DA, Shrader B. 1989. Transforming growth factor beta specifically enhances IgA production by lipopolysaccharide-stimulated murine B lymphocytes. J Exp Med 170: 1039-1044. [Medline] [CrossRef]

28. Kim PH, Kagnoff MF. 1990. Transforming growth factor-beta 1 is a costimulator for IgA production. J Immunol 144: 3411-3416. [Medline]

29. He B, Xu W, Santini PA, Polydorides AD, Chiu A, Estrella J, Shan M, Chadburn A, Villanacci V, Plebani A, Knowles DM, Rescigno M, Cerutti A. 2007. Intestinal bacteria trigger $\mathrm{T}$ cell-independent immunoglobulin $\mathrm{A}(2)$ class switching by inducing epithelial-cell secretion of the cytokine APRIL. Immunity 26: 812-826. [Medline] [CrossRef]

30. Xu W, He B, Chiu A, Chadburn A, Shan M, Buldys M, Ding A, Knowles DM, Santini PA, Cerutti A. 2007. Epithelial cells trigger frontline immunoglobulin class switching through a pathway regulated by the inhibitor SLPI. Nat Immunol 8: 294-303. [Medline] [CrossRef]

31. Castigli E, Wilson SA, Scott S, Dedeoglu F, Xu S, Lam KP, Bram RJ, Jabara H, Geha RS. 2005. TACI and BAFF-R mediate isotype switching in B cells. J Exp Med 201: 35-39. [Medline] [CrossRef]

32. Mora JR, Iwata M, Eksteen B, Song SY, Junt T, Senman B, Otipoby KL, Yokota A, Takeuchi H, Ricciardi-Castagnoli P, Rajewsky K, Adams DH, von Andrian UH. 2006. Generation of gut-homing IgAsecreting B cells by intestinal dendritic cells. Science 314: 1157-1160. [Medline] [CrossRef]

33. Mora JR, von Andrian UH. 2008. Differentiation and homing of IgA-secreting cells. Mucosal Immunol 1: 96-109. [Medline] [CrossRef]

34. Tezuka H, Abe Y, Iwata M, Takeuchi H, Ishikawa H, Matsushita M, Shiohara T, Akira S, Ohteki T. 2007. Regulation of IgA production by naturally occurring TNF/iNOS-producing dendritic cells. Nature 448: 929-933. [Medline] [CrossRef] 